\title{
Role of physical education in antique educational system
}

\author{
Ludmila Demyanova ${ }^{1}$, Irina Usova $^{2, *}$, Elena Ishchenko $^{3}$, Nadezhda Djyakonova ${ }^{3}$, and \\ Sergey Demyanov ${ }^{1}$ \\ ${ }^{1}$ Don State Technical University, 344003, Gagarin Square 1, Rostov-on-Don, Rostov region, Russia \\ ${ }^{2}$ Institute of Technologies (branch) of DSTU in Volgodonsk, 347386, Mira Avenue 16, Volgodonsk, \\ Rostov region, Russia \\ ${ }^{3}$ Southern Federal University, 344000, Bolshaya Sadovay St. 105, Rostov-on-Don, Rostov region, \\ Russia
}

\begin{abstract}
The article deals with the place occupied by physical healthimproving practices in the system of ancient education. The preconditions are revealed, based on which the ancient Greeks considered it necessary to develop bodily qualities in addition to spiritual ones. Revealed the goals that the ancient Greeks pursued during the upbringing of the younger generation. The authors separately consider both the Spartan teaching system and the Athenian one. Using a comparison method, the authors identified differences as well as similarities in physical education in Sparta and Athens. In addition to youth education, the authors consider what the education of girls was like in antiquity. The article reveals the attitude of the ancient Greeks to sports competitions, in particular, to the Olympic Games. The authors also tell what educational system formed the basis of the ancient Roman teaching of young men.
\end{abstract}

\section{Introduction}

Today we can say that not all students of educational institutions, be it primary education (school), secondary specialized education (college, technical school) or higher education (higher education institution) are definitely positive about the fact that, in addition to core subjects, they also have to engage in activities related to physical and health-improving practice. So A. G. Tertyshnikova and A. N. Werner write in their article "the majority of young people do not consider it necessary to engage in any kind of sports" $[1-13]$.

\section{The historical aspect of the study of physical activity in the educational process}

\footnotetext{
*Corresponding author : irina_usova@mail.ru
} 
To confirm the hypothesis, the authors turned to a study that was conducted in the spring of 2017 on the basis of the sociological laboratory in the RUDN University in which 301 people were interviewed including 153 schoolchildren aged 14 to 18 and 148 students from 17 to 23 years old. The sample was random [13] (Figure 1).

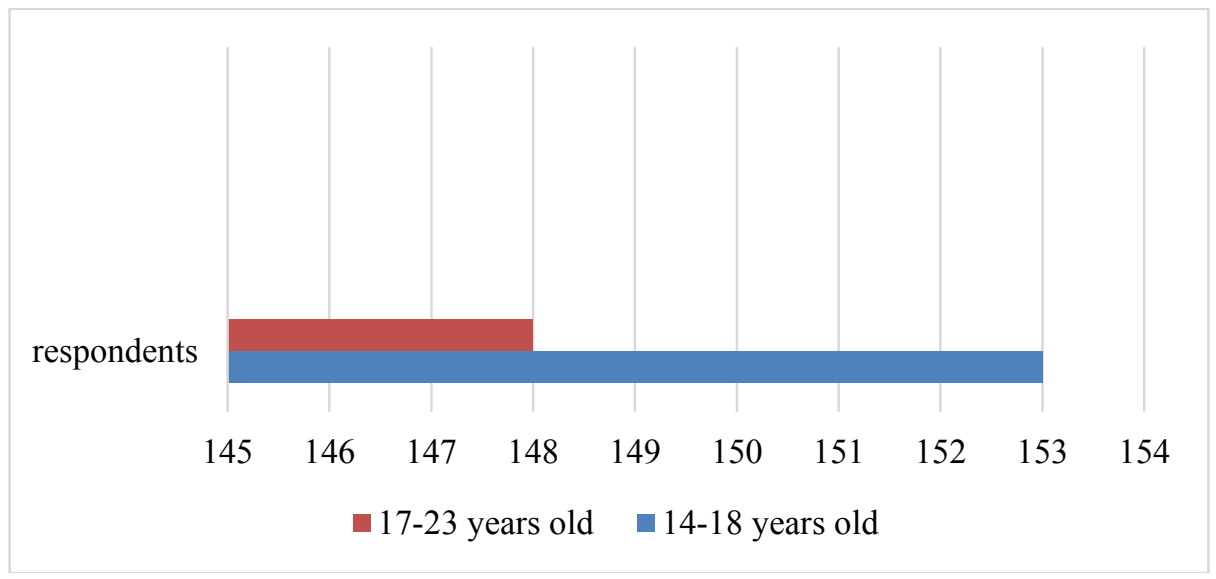

Fig. 1. Health indicators of the 1-3 courses students

In this survey the researchers tried to find out what is the attitude of young people to sports, whether they go to the sports sections of their educational institutions.

When asked about classes in sports clubs organized on the basis of an educational institution, the majority of respondents answered that they are not engaged in any of the sections (77.6\% of schoolchildren, $63.3 \%$ of students) [13].

Also, in one of the questions, the respondents were asked to select the main reasons why most young people do not go in for sports. Most of the students believed that the reason for this was the lack of desire to study (56\%) among schoolchildren this opinion was shared by $5 \%$ of the respondents [13. P. 168].

Thus despite the fact that not all of the younger generation is involved in sports activities, each state in its education system pays a great role to the physical education of the younger generation. The following question arises what is the reason for the mandatory introduction of physical activity into the educational process? By passing this issue from the point of view of physiology and psychology, you can look at it from a historical point of view, where the brightest example will be antiquity, which in turn had a huge impact on the entire Western European culture.

As for this issue, it was investigated by such authors as V.V. Romanova and I. Vunzhe, E.A. Filimonova, D.I. Dmitriev, V.K. Pichugin, A.A. Artemiev and I. L. Levina, N. A. Gasimova, T. V. Sleptsova and L. G. Pushkareva, N. V. Demchuk and A. S. Morozov, A. S. Alexandrova and A. G. Smetanin, V. V. Gruzin and A.I. Gruzina, D. G. Khromykh, B. A. Amanova, Yu.S. Rakoed and G. A. Khabibuullina, A. A. Knyazev and N. P. Lyubetsky, A. A. Bochkarev and others.

To understand the role of physical education in antiquity, it is necessary to analyze how education took place in the policy. How did the education of young Greeks begin?

According to A. A. Artemiev and I. L. Levina, in ancient Greece there were at least two educational systems that were significantly different from each other. Of the many fragmented and warring city-states (policies), Athens and Sparta stand out in ancient Greece. As leaders on the entire coast, these states had a specific structure of economy, politics and social life. As a result, the approaches to the upbringing and training of the 
younger generation among the Spartans and the Athenians also differed. For a clearer understanding of these differences, it is necessary to examine in more detail each tradition of education.

Among the Greek city-states, Athens was the center of trade and handicraft. This created a special atmosphere conducive to the development of secular culture. In Athens, philosophers and poets gathered, theatrical performances, sports competitions and public performances were held. Against this background, the Athenian image of an ideal person was formed - harmoniously developed in all respects, beautiful both in body and soul. In order to develop all aspects of man a whole system of various schools operated in Athens. Until the age of 7 boys were brought up at home under the supervision of a teacher (slave), but after the age of seven, their education began in one of the schools of music. There children received basic knowledge of arithmetic, were introduced to literature and music. From the age of 12 in addition to attending a musical school young Greeks began to go to the Palestinians, where their physical education began. The young men swam in pools, worked out in gymnasiums and practiced jogging. With the achievement of the age of sixteen, classes in musical schools and Palestinians ended, after which the children of the most respectable parents could enter a special educational institution - gymnasium, where more serious physical training and active involvement of young men in public life began. The final stage of Athenian education was the passage of three years of training in Ephebia, where Athenian youths received the necessary skills of military craft: "After graduating from this school, those who distinguished themselves became warriors, and the rest mastered one of the crafts or were engaged in trade and agriculture"[8. P. 106].

During their studies in schools of music, palaestra and gymnasium, young Athenians were not separated from their family and continued to live with her. This is due to the fact that these schools, with the exception of gymnasiums, were private.

Girls in Athens did not receive such a diverse education as young men. Their training took place in the female half of the house - "gynekey", first of all they were taught needlework, singing and basic skills of playing musical instruments. All the girls' physical education consisted of teaching dance.

The Athenian educational system is a clear example of what the ancient Greeks saw as the ideal, namely, in harmony. "The ideal of the Athenian upbringing in the conditions of a slave-owning democracy was a person who was harmoniously developed physically and mentally from among wealthy citizens and aristocrats" [2. P. 134]. The Athenians especially emphasized the aesthetic beauty of a physically developed and healthy body: "In Athens, beauty played the first role, not strength" [10. P. 88].

Athens appreciated a well-rounded personality who could show herself on a good side in any business. But what is the reason for such a demand for a universally developed citizen? This is primarily due to the ideas of the Greeks about human nature. Ontologically, a person is presented as a "microcosm", each person is a whole world, similar to the one in which he himself dwells. And just as the cosmos, or the world, is harmonious in itself, so a person must be harmonious.

It is also important to note religious beliefs, in particular, the ideal of the Hellenes. The images of the gods at different times were evaluated differently by the ancient Greeks, but for the most part the gods personified an ideal that is not attainable by man. The Greeks also saw the hero as an ideal person, who, despite his human nature, was able to overcome his nature thanks to intellect and physical skills. The image of an ideal person was correlated with the images of gods and heroes [14. P. 167].

A special role in Greek culture was assigned to competitions, the main of which were the Olympic Games, held in honor of the main god of the ancient Greek pantheon, Zeus. The Olympic Games became the center of unification of all artists, philosophers and poets, the games were held extremely solemnly and majestically [3. P. 14]. During the Olympics, 
the policies had to forget about their feuds, a short truce ensued throughout Greece. This fact testifies to the fact that the Greeks had great respect for sports competitions, strictly following the order during the Olympic Games.

It should be noted that the Romans in the organization of education were largely guided by the experience of the Athenians, but with certain differences. So, in ancient Rome, the harmonious development of body and spirit was also considered an ideal. The upbringing of young Romans was led primarily by the father, the state could only in extreme cases interfere in the family affairs of citizens. In Rome, young men attended private schools, where they learned how to read and develop physically.

In the understanding of the Greeks, a person was an integral element of society. A person is a social being, the unity of man and society was perceived as one whole [8. P. 105]. From their youth, the Athenians prepare their children for social life. As future adults, they should have all the skills that are necessary for social life. This includes arts, crafts, intellectual skills and, one of the main, the ability to stand up for yourself and your state, for your policy.

The ability to defend and defend itself was especially cultivated in Sparta, which is why the upbringing of young Spartans, in contrast to the Athenian ones, was more rigid and harsh. Sparta was an authoritarian, militarized society, where strength and courage were considered the ideal, and the whole life of citizens was under the control of the state. The upbringing of the younger generation was subordinated to a single goal - to bring up strong warriors capable of enduring the hardships of military life. Those among the Spartans who showed cowardice on the battlefield were exposed to public shame, both from other Spartans and from their families. In order to educate strong and obedient soldiers, the state needed to tightly control the process of education. From the very birth, children were subjected to harsh selection: the parents had to show the newborn child to the council of elders, which left him alive if he, in their opinion, was absolutely healthy [6. P. 23]. Until the age of 7 , the child was brought up by his parents, during this period the main attention was paid to his tempering, the child was not allowed to pamper and teach him to an idle life.

After the little Spartan turned 7 years old, he was assigned to a special state educational institution - agella. There, the children were distributed into groups and their training was supervised by a payon, chosen from among the respected Spartans. During their training in agella, young Spartans received the necessary literacy skills, but most of the training was engaged in initial physical training, pentantlon, and tempering. It is worth emphasizing that children mastered writing and reading only at the minimum required level, the demonstration of special eloquence was strictly suppressed. Future Spartans had to express themselves clearly and concisely - like military reports, their speeches were supposed to carry only information, without any poetics and beauty. Children always walked barefoot, slept on thin straw mats; at all seasons, teenagers used a light raincoat as outerwear [6]. This is how their training took place until the age of 15 . To move to the next level of training, the young men had to go through a public section at the altar of Artemis Ortia, during which they had to demonstrate their endurance and ability to endure pain. The final stage before initiation into adolescents was participation in the crypt: groups of 30-40 people, under the guidance of their tutor, passed a kind of training in the area of the rebellious villages of helots [6]. During this teaching the young men had to catch the rebellious helots and kill them.

After successfully passing the crypt and a public section at the altar of Artemis Ortia, the young Spartans were officially transferred to teenage status and joined the ranks of the Eirens. From this point onwards, the training program includes drills and the use of weapons. General physical training takes place in the framework of pentathlon (pentathlon), which included running, jumping, wrestling, discus and javelin throwing. A distinctive 
feature of training in Sparta was the so-called "Spartan gymnastics", which was training in hand-to-hand fighting skills. Upon reaching the age of twenty, the Eirens moved on to the last stage of training and, until the age of 30, were called ephebes. During these ten years, young men honed their physical shape and gained military experience. Only upon reaching the age of thirty did the Spartans receive political rights and had the right to be called husbands. Thus, we see that the full realization of the right to participate in public life appeared in the Spartan only when he reached the peak of his physical form.

As for the Spartans, until the age of 20, they studied on a par with young men: they also did gymnastics and combat exercises. The ancient Greek historian, Plutarch, commented on this position in the following way: “... The girls also practiced running, wrestling, throwing a disc and a spear, so that their bodies were strong and strong, and so were the children they were born with. Hardened by such exercises, they could more easily endure the pangs of childbirth and get out of them healthy" [6. P. 25]. The reason for the presence of military training in Spartan women can be called the fact that during the absence of their husbands, women had to maintain order in Sparta, to ensure that the rebels from among the slaves did not riot. The revolt, from the side of the subordinate population, was an urgent problem, for in Sparta "there were almost 200 thousand slaves, 30 thousand semi-free helots and 9 thousand Spartans" [1. P. 6]

Having examined in detail each educational system, we can say that great attention was paid to physical development, especially among the Spartans. In both Sparta and Athens, education was revered as an essential quality of every worthy citizen. "If they wanted to say something bad about a person, they said, for example: "He can neither read nor swim " [7. P. 235]. The concept of education necessarily included good physical shape as well. So, for example, in Sparta, helots - dependent farmers, did not have the right to engage in training, for this prerogative was only with free Spartans.

\section{Conclusion}

Thus we can conclude that the entire ancient worldview is based on one dominant thought the body and the soul require the same development, if the goal is to educate a person who is able to overcome adversity, to be ready to protect both himself and his loved ones, his country. Physical training hardens not only the body, but also the soul, making it more resilient, able to endure hardships, adapt to new conditions and fight adversity. The ancient Greeks perfectly felt this correlation between physical education and the moral formation of the younger generation. The education of the soul is impossible without the education of the body, a harmonious personality combines these two principles, without opposing them to each other [12]. Of the many ancient Greek city-states, two distinct polices stood out clearly - Sparta and Athens. Developed both culturally and materially, the Athenians strove for harmony of body and soul, saw the goal of training in the upbringing of worthy citizens of their polis, who could not only protect their country, but also serve the cultural development of their state. Sparta formed from its citizens, first of all, warriors strong in spirit and body, before whom the only task was to win and not be defeated. In both Sparta and Athens, training began at the age of 7 and had several levels, overcoming which young men could become full citizens of their policies. In pursuit of different ideological goals, both Sparta and Athens cultivated the image of a strong and resilient person. In the view of the ancient Greeks, volitional qualities were directly related to the physical strength of a person, therefore, in antiquity they saw it as mandatory to practice physical education of the younger generation, with a gradual increase in stress and complexity. 


\section{References}

1. A. S. Alexandrova, Modern trends in the development of science and technology, 4, 5$6(2016)$

2. Yu. Tatur, Modern Olympic sports and sports for all, 3, 45-46 (2018)

3. I. V. Manzheley, S. N. Cherniakova, Vestnik of Tyumen State University. Pedagogy. Psychology, 9, 78-91 (2014)

4. V. V. Gruzin, Scientific discussion: questions of pedagogy and psychology, 48, 28-33 (2016)

5. N. V. Demchuk, Scientific discussion: questions of sociology, political science, philosophy, history, 56, 22-29 (2017)

6. N. V. Demchuk, Science and innovations in the XXI century: topical issues, discoveries and achievements, 1, 234-237 (2017)

7. D. I. Dmitrieva, Modern high technology, 5, 104-108 (2017)

8. L. Demyanova, O. Mavropulo, I. Usova, E3S Web Conf. XIII International Scientific and Practical Conference "State and Prospects for the Development of Agribusiness INTERAGROMASH 2020", 175

(2020) DOI: https://doi.org/10.1051/e3sconf/202017515025

9. Y. S. Rakoed, Physical education of Siberia, 5, 84-89 (2017)

10. V. V. Romanova, Actual problems of the humanities and socio-economic sciences, 4 , 78 (2013).

11. T. V. Sleptsova, Physical education of Siberia, 2, 73-76 (2015)

12. A. G. Tertyshnikova, Advanced experience of social and pedagogical work with children and family, 6, 165-169 (2017)

13. E. A. Filimonova, Bulletin of the Siberian Institute of Business and Information Technologies, 4(20), 166-173 (2016)

14. D. G. Khromykh, Ancient languages and modernity, 3, 154-159 (2017)

15. M. Griffith, A Companion to Ancient Education, 26-60 (2015) 